University of Nebraska - Lincoln

DigitalCommons@University of Nebraska - Lincoln

2006

\title{
Survey of Community Knowledge, Attitudes, and Practices During a Malaria Epidemic in Central Java, Indonesia
}

\author{
Parsa Sanjana \\ Family Health International \\ Mazie J. Barcus \\ Hydas World Health \\ Michael J. Bangs \\ U.S. Navy Disease Vector Ecology and Control Center \\ Sahat Ompusunggu \\ LITBANGKES \\ Iqbal Elyazar \\ U.S. Naval Medical Unit \# 2 \\ See next page for additional authors
}

Follow this and additional works at: https://digitalcommons.unl.edu/usnavyresearch

Sanjana, Parsa; Barcus, Mazie J.; Bangs, Michael J.; Ompusunggu, Sahat; Elyazar, Iqbal; Marwoto, Harijani; Tuti, Sekar; Sururi, Mohammed; Tjokrosonto, Soesanto; and Baird, J. Kevin, "Survey of Community Knowledge, Attitudes, and Practices During a Malaria Epidemic in Central Java, Indonesia" (2006). U.S. Navy Research. 61.

https://digitalcommons.unl.edu/usnavyresearch/61

This Article is brought to you for free and open access by the U.S. Department of Defense at DigitalCommons@University of Nebraska - Lincoln. It has been accepted for inclusion in U.S. Navy Research by an authorized administrator of DigitalCommons@University of Nebraska - Lincoln. 


\section{Authors}

Parsa Sanjana, Mazie J. Barcus, Michael J. Bangs, Sahat Ompusunggu, lqbal Elyazar, Harijani Marwoto, Sekar Tuti, Mohammed Sururi, Soesanto Tjokrosonto, and J. Kevin Baird 


\title{
SURVEY OF COMMUNITY KNOWLEDGE, ATTITUDES, AND PRACTICES DURING A MALARIA EPIDEMIC IN CENTRAL JAVA, INDONESIA
}

\author{
PARSA SANJANA, MAZIE J. BARCUS, MICHAEL J. BANGS, SAHAT OMPUSUNGGU, IQBAL ELYAZAR, \\ HARIJANI MARWOTO, SEKAR TUTI, MOHAMMED SURURI, SOESANTO TJOKROSONTO, AND J. KEVIN BAIRD* \\ Rollins School of Public Health, Emory University, Atlanta, Georgia; U.S. Naval Medical Research Unit No. 2, Jakarta, Indonesia; \\ Center for Disease Control, Research and Development, National Institute for Health Research and Development, Ministry of Health, \\ Jakarta, Indonesia; Purworejo Health Service, Purworejo, Central Java, Indonesia; Gajah Mada University, Yogyakarta, Indonesia
}

\begin{abstract}
We surveyed adults in a randomly selected sample of 1,000 households in 50 villages in nine malarial sub-districts in Purworejo, central Java, Indonesia from May to July 2001. The survey assessed malaria knowledge, attitudes, and practices in communities experiencing epidemic malaria to begin exploring broad strategies for controlling the disease in the region. A pre-tested survey instrument consisting of 93 questions addressed demographic characteristics, socioeconomic factors, knowledge and perceptions of malaria, burden and severity of disease, treatment-seeking behavior, malaria prevention practices, and perceptions of government malaria control efforts. The survey was taken by in-person interview of all subjects. Most (97\%) subjects were aware of malaria and more than two-thirds correctly identified mosquitoes as the vector. Forty-one percent of households in both forest/hilly and agricultural/urban areas reported malaria illness in the past year. Thirty-six percent (357 households) owned at least one bed net, $92 \%$ of these had been purchased by the owners. However, only $36 \%$ of households with bed nets affirmed their use as a means of preventing malaria. Nearly all respondents reported a willingness to accept spraying of residual insecticides for malaria prevention, yet less than 5\% were willing to pay a nominal fee (US \$3) for this service. Fifty-two percent of respondents reported self-treatment of malaria illness without visiting a health facility. This assessment of knowledge, attitudes, and practices showed a broad awareness of malaria and its consequences among residents of malarial areas in the Menoreh Hills of Central Java.
\end{abstract}

\section{INTRODUCTION}

Malaria infects hundreds of millions of people each year ${ }^{1}$ and is recognized as a serious re-emerging threat to public health. Beginning in the early 1970s, soon after abandonment of the World Health Organization Global Eradication Program that focused on vector control and onset of widespread resistance to chloroquine, the range and intensity of epidemic and endemic malaria has expanded. ${ }^{2}$ The losses of DDT and chloroquine to effectively control malaria have been seriously compounded by the general deterioration of research activities aimed at developing effective alternative strategies. ${ }^{2,3} \mathrm{Al}-$ though substantial investments have been made in research aimed at developing specific tools of potential use to malaria control (bed nets, rapid diagnostics, drugs, and vaccines) little work has been funded to explore consolidating those instruments of control into rational, coherent, and sustainable intervention strategies.

Widespread hyperendemic malaria on the island of Java was brought under control after 1952 when the Republic of Indonesia, with financial and technical assistance from the U.S. government, began an indoor residual spray program using primarily DDT and mass treatment with chloroquine., The malaria slide-positive rate in many areas rapidly decreased from approximately $25 \%$ to less than $1 \% .^{5}$ Those efforts, continued and expanded over the next 10 years, further reduced the annual incidence of malaria on Java and Bali from 1.3 cases per 1,000 residents in 1963 to $<0.15$ cases per 1,000 residents in $1965 .^{5}$ Malaria was virtually eradicated from Java and Bali with the exception of small refractory foci of hypoendemic disease in remote areas of central Java. Data from as recently as 1993 indicate that the annual incidence of

* Address correspondence to J. Kevin Baird, ALERTAsia Foundation, Eijkman Institute of Molecular Biology, Jalan Diponegoro No. 69, Menteng, Jakarta 10430, Indonesia. E-mail: jkevinbaird@ yahoo.com malaria had remained as low as 0.15 cases per 1,000 residents, with most of those infections coming from isolated pockets of persistent low transmission. ${ }^{5}$

In the late 1980s, Indonesia abandoned the use of DDT for malaria control. Indoor household spraying with alternative residual insecticides such as fenitrothion and bendiocarb continued but the relatively high cost of these alternatives forced vector control programs to drastically reduce coverage. ${ }^{6}$ The east Asian economic crisis of 1997-1998 severely impacted malaria control efforts and brought an end to sustained vector control efforts in Indonesia. An epidemic of malaria in the Menoreh Hills of central Java commenced at this time; between 1996 and 2000 the annual parasite incidence increased from 4 to 45 infections per 1,000 residents ${ }^{6}$. In this setting, we conducted a survey of knowledge, attitudes, and practices of malaria in and around the Menoreh Hills from May to July 2001.

\section{MATERIALS AND METHODS}

Study site. Purworejo District, located in central Java, consists of 494 villages in 16 sub-districts. ${ }^{7}$ The northern and eastern districts include the Menoreh Hills and the foothills of the Dieng Plateau. The Indian Ocean borders the southern coastal zone, while a broad low plain dominates the central zone. A 1999 census indicated approximately 770,000 people living in the district. Of these, an estimated 414,000 people resided in hills, 230,000 in plains, and 127,000 in the coastal zone. Most residents engage in cultivating rice, clove, teak, balsa, and coconut. ${ }^{6}$

Survey instrument. A survey instrument consisting of 93 questions addressed the following major categories: demographic characteristics, socioeconomic indicators, knowledge and perceptions of malaria, burden and severity of disease estimates, treatment-seeking behavior practices in the past year, personal prevention practices, and perception of government-sponsored malaria control efforts. The survey instrument, originally composed in English language, was trans- 
lated to Indonesian language and then translated back into English to identify and clarify ambiguities or misunderstandings attributable to translation. For convenience and understanding, most interviews were conducted in the native Javanese language vice Indonesian.

Sampling and collection. The sample was restricted to the nine sub-districts in Purworejo reporting year 2000 malaria surveillance statistics reflecting greatest risk. All were in the Menoreh Hills or the foothills of the Dieng Plateau. We randomly selected 50 villages from these 9 sub-districts from listings of all villages within sub-districts. A specific protocol guided two survey teams for random sampling of households within villages. Trained teams began with visiting the household of the head of the village. Each team then walked approximately 100 meters from that house in opposite directions along set compass headings. The house closest to that point was then sampled. Each team repeated this sampling protocol, moving along their respective assigned compass headings until completing 10 households each per village.

Four local residents hired and trained for this task conducted the collection of answers from the survey instrument. The interviewers had at least a high school education, could speak, read, and write the Indonesian language, and spoke fluent Javanese as a first language. Training consisted of strict adherence to the sampling protocol, informed consent, and conduct of the interview. The teams requested to interview the head of household, but any resident more than 15 years of age could serve as an interview subject. Interviews were typically conducted in the residence living room area often with several family members present and providing input by means of discussion. Direct observation of the first 12 interviews (3/interviewer) was followed by modifications to wording of some questions to improve clarity. Ten selected households $(<1 \%)$ refused to participate in the survey.
The data were entered and analyzed using EpiInfo version 6 (Centers for Disease Control and Prevention, Atlanta, GA) and SPSS version 10 (SPSS, Inc., Chicago, IL). The chi-square test was used to assess differences in proportions. $P$ values for odds ratios were calculated using the Mantel-Haenszel method. When expected cell values were $<5$, the exact confidence limits were reported. $P$ values $\leq 0.05$ were considered statistically significant.

Ethical considerations. This study was reviewed and approved by Institutional Review Boards for the ethical conduct of research on human subjects at the U.S. Naval Medical Research Unit No. 2 in Jakarta, the National Institutes of Health Research and Development, Ministry of Health, Republic of Indonesia, and Emory University School of Medicine in Atlanta, Georgia. The respective Departments of Health for the Province of Central Java and Purworejo District reviewed and approved the study.

\section{RESULTS}

Demographic characteristics. Table 1 lists the demographic and socioeconomic data for the study population. The median age of the 1,000 respondents interviewed was 40 years, ranging from 15 to 85. The male:female ratio was 1:1.2. Eight hundred fifty-nine respondents $(86 \%)$ were married; the remainder being single, divorced, or widowed. The respondents were predominantly Muslim (99\%) with Buddhists and Christians composing the remainder. The median household size was 4 people (range $=1-11$ ). Respondents were predominantly native to the district of Purworejo (96\%). Most formal schooling was limited to elementary school and farming was the main occupation. Four hundred seventeen respondents $(42 \%)$ had a secondary source of income such as home industry, small business, fish farming, or seasonal work. For

TABLE 1

Demographic, socioeconomic, and burden of disease factors of study population Purworejo District, Indonesia, May-July 2001*

\begin{tabular}{|c|c|c|c|c|c|}
\hline & & $\begin{array}{l}\text { Hill/forest } \\
\text { areas } \\
\text { No. }(\%)\end{array}$ & $\begin{array}{l}\text { Paddy/urban } \\
\text { area } \\
\text { No. (\%) }\end{array}$ & Total & $P$ \\
\hline \multirow[t]{4}{*}{ Demography } & Number of respondents & $480(48 \%)$ & $520(52 \%)$ & 1,000 & 0.205 \\
\hline & Median age & 38 & 40 & 40 & 0.053 \\
\hline & Male:female ratio & $1: 1.5$ & $1: 1$ & $1: 1.2$ & $0.002 \dagger$ \\
\hline & Median number people in family & 4 & 4 & 4 & $0.034 \dagger$ \\
\hline \multirow{5}{*}{$\begin{array}{l}\text { Physical make-up of house } \\
\text { (type of wall) }\end{array}$} & Bamboo & $54(11.3)$ & $50(9.6)$ & $104(10.4)$ & 0.398 \\
\hline & Wood & $74(15.4)$ & $45(8.7)$ & 119 (11.9) & $<0.001 \dagger$ \\
\hline & Cement & $91(18.9)$ & $104(20.0)$ & $195(19.5)$ & 0.678 \\
\hline & Brick & $123(25.6)$ & $131(25.2)$ & $254(25.4)$ & 0.875 \\
\hline & Mixed materials & 137 (28.6) & $190(36.5)$ & $314(31.4)$ & $0.007 \dagger$ \\
\hline Size of house & Median number of rooms in house & 5 & 5 & 5 & 0.919 \\
\hline \multirow[t]{2}{*}{ Barriers to insects } & $\%$ of home without screens over windows & $470(97.9)$ & $510(98.1)$ & $980(98.0)$ & 0.856 \\
\hline & $\%$ of homes without glass over windows & $111(23.1)$ & 164 (31.6) & $275(27.5)$ & 0.003 \\
\hline \multirow{4}{*}{$\begin{array}{l}\text { Primary occupation of } \\
\text { respondent }\end{array}$} & Merchandiser/trader & $26(5.4)$ & $31(6)$ & $57(57.0)$ & 0.71 \\
\hline & Government employee & $33(6.9)$ & $35(6.9)$ & $68(68.0)$ & 0.928 \\
\hline & Retired & $15(3.1)$ & $26(5)$ & $41(41.0)$ & 0.135 \\
\hline & Other & $71(14.8)$ & $92(17.7)$ & $163(16.3)$ & 0.215 \\
\hline \multirow[t]{3}{*}{ Educational level of respondent } & Secondary school & 70 (14.6) & $100(19.2)$ & $170(17)$ & 0.051 \\
\hline & Senior high school & $50(10.4)$ & $72(13.8)$ & $122(12.2)$ & 0.098 \\
\hline & College or higher & $7(1.5)$ & $7(1.3)$ & $14(1.4)$ & 0.88 \\
\hline \multirow[t]{2}{*}{ Burden of disease } & "Heard of malaria" & $467(97.3)$ & $505(97.1)$ & $972(97.2)$ & 0.866 \\
\hline & $\begin{array}{l}\% \text { of households reporting malaria in the past } \\
\text { year }\end{array}$ & $197(41.0)$ & $212(40.8)$ & $409(40.9)$ & 0.93 \\
\hline IRS & $\begin{array}{l}\% \text { of households ever sprayed with residual } \\
\text { insecticides }\end{array}$ & $277 / 476(58.2)$ & $342 / 518(66.0)$ & $619(62.3)$ & $0.011 \dagger$ \\
\hline
\end{tabular}

* IRS $=$ indoor residual spraying.

$\dagger$ Significant difference. 
place of residency, $61 \%, 35 \%$, and $4 \%$ lived in hill, lowland rice paddy, and urban areas, respectively. A total of 928 respondents $(93 \%)$ reported owning their own home.

The size of the houses ranged from 1 to 10 rooms (including bedrooms), with a median of 5 rooms and 3 bedrooms. The walls were constructed of a variety of materials, including brick $(25 \%)$, cement $(20 \%)$, plank wood $(12 \%)$, bamboo $(10 \%)$, or a combination of these materials (31\%). Less than $1 \%$ of houses had screens over the window openings, but $72 \%$ had some or all window areas covered with glass or plastic. Of the 851 respondents $(85 \%)$ who raised animals, many had chickens, ducks and goats, with only a few households husbanding cattle or water buffalo. Of respondents with animals, $775(91 \%)$ confined them within 20 meters of their house. We found few differences among the demographic and socioeconomic data collected between residents of hills/forested areas and those living in rice paddy or urban areas. The male: female ratio of the respondents and the median number of people in the family were both statistically different; however, the difference was of no practical importance. The physical make-up of the homes was different between the two groups. Paddy/urban homes were made more with mixed materials and used more glass window coverings. Forest/hill homes were more likely to be made from wood.

Knowledge of malaria. When asked, "have you heard of malaria?" 972 respondents (97\%) stated yes. Of this group, $69 \%$ (671 of 972) correctly identified mosquitoes as the main vector of malaria transmission. Incorrect responses included stagnant water, unclean environment, climate, other illness, and sour tasting food as sources of malaria infection.

Table 2 lists the sources of malaria knowledge cited by respondents. Five hundred six respondents (52\%) heard of malaria from neighbors and 255 (26\%) received information from local government health workers. Other sources of information included the health center, media (newspaper, radio, television), relatives, friends, midwives, and school. Residents of paddy/urban areas were more likely to cite both the health center and the family welfare group as sources of malaria knowledge.

Most residents correctly associated the typical clinical symptoms with malaria attacks. Nine hundred seven respondents $(93 \%)$ reported fever and chills as primary indicators of malaria illness. Nausea and vomiting $(17 \%)$, headache $(7 \%)$, fatigue $(5 \%)$, and dizziness $(5 \%)$ were also cited. Only 49

TABLE 2

Sources of malaria knowledge cited by respondents $(n=972)$ in Purworejo District, Indonesia, May-July 2001 (multiple responses possible)

\begin{tabular}{lcccc}
\hline \multicolumn{1}{c}{ Source of knowledge } & \% Hills/forest & \% Paddy/urban & \% Total & $P$ \\
\hline Neighbor & 52.7 & 51.5 & 52.1 & 0.71 \\
Health worker & 24.8 & 27.5 & 26.2 & 0.34 \\
Health center & 13.1 & 20.6 & 17.0 & $0.002^{*}$ \\
Relative & 7.9 & 10.3 & 9.2 & 0.20 \\
School & 7.7 & 9.3 & 8.5 & 0.37 \\
Midwife & 9.0 & 5.5 & 7.2 & $0.04 *$ \\
Friend & 6.2 & 7.3 & 6.8 & 0.49 \\
Family welfare group & 3 & 9.1 & 6.2 & $<0.001^{*}$ \\
Media (newspaper, & & & & \\
$\quad$ radio, TV) & 5.8 & 6.5 & 6.2 & 0.63 \\
Religious group & 1.7 & 2.6 & 2.2 & 0.36 \\
Other & 0.4 & 0.8 & 0.7 & 0.47 \\
\hline * Significant difference. & & & &
\end{tabular}


TABLE 3

Malaria prevention practices mentioned by households $(\mathrm{n}=1,000$ in Purworejo District, Indonesia, May-July 2001 (multiple responses possible)

\begin{tabular}{|c|c|c|c|c|}
\hline $\begin{array}{l}\text { Action } \\
\text { (multiple responses possible) }\end{array}$ & $\begin{array}{c}\% \\
\text { Hills/forest }\end{array}$ & $\begin{array}{c}\% \\
\text { Paddy/urban }\end{array}$ & $\%$ Total & $P$ \\
\hline Keep house clean & 47.3 & 61.5 & 54.7 & $<0.001^{*}$ \\
\hline $\begin{array}{l}\text { Take jamu (traditional } \\
\text { medicine) }\end{array}$ & 17.1 & 19.6 & 18.4 & 0.30 \\
\hline Use larvicide/coil & 14.4 & 17.3 & 15.9 & 0.21 \\
\hline Use bed nets & 9.8 & 17.7 & 13.9 & $<0.001 *$ \\
\hline Take pills & 14.0 & 12.7 & 13.3 & 0.56 \\
\hline Indoor residual spray & 11.9 & 13.5 & 12.7 & 0.45 \\
\hline Eat well & 3.3 & $\begin{array}{l}4.0 \\
4.8\end{array}$ & 4.1 & $\begin{array}{l}0.20 \\
0.24\end{array}$ \\
\hline Avoid sour food & 0.4 & 1.3 & 0.9 & 0.12 \\
\hline Burn trash & 0.4 & 0.6 & 0.5 & 0.72 \\
\hline $\begin{array}{l}\text { Avoid those with } \\
\text { malaria }\end{array}$ & 0.6 & 0 & 0.3 & 0.07 \\
\hline $\begin{array}{l}\text { Keep animals out } \\
\text { of house }\end{array}$ & 0.2 & 0.2 & 0.2 & 0.96 \\
\hline Nothing & 2.7 & 2.3 & 2.5 & 0.69 \\
\hline Other & 4.8 & 2.3 & 3.5 & $0.03 *$ \\
\hline
\end{tabular}

* Significant difference.

from a health worker, two from a non-governmental organization assisting in malaria control, and three from the government services; all but one of these households received the net at no cost. Overall, 190 respondents (53\%) with bed nets paid less than 20,000 rupiah (US\$2) per net, 116 (33\%) paid between 20,000 and 50,000 rupiah, and 21 (0.6\%) paid more than 50,000 rupiah (US\$5). No information was gathered as to the type of bed net used or whether it had been treated with insecticides before or after purchase.

Of the 357 households with bed nets, 181 (51\%) reported that all household members slept under bed nets. Thirty-three $(9.2 \%)$ reported no bed net use among household members, and $143(40 \%)$ reported that only some household members slept under the nets. A median of three people (range $=0-8$ ) per household had slept under a bed net the previous night, and a median of one household member (range $=1-9$ ) had not. The mean family size for households with bed nets was 4.2 people, which is equivalent to overall household size. There was no association between households owning bed nets and reporting a household member ill with malaria in the past year $(\mathrm{OR}=1.0, P=0.892)$. Only $36 \%$ of households with bed nets affirmed its use as a means of preventing malaria.

Indoor residual spraying. Reported indoor residual spraying with an insecticide ranged from $15 \%$ to $100 \%$ of households surveyed in the 50 villages. Six hundred nineteen houses $(62 \%)$ remembered having been sprayed with an insecticide at one time in the past, although the reported time since the last spraying varied. Paddy/urban residents reported less spray activity in the past year when compared with hills/forest residents $(10 \%$ versus $30 \%)$, more spray activity in the past $1-4$ years $(30 \%$ versus $19 \%)$, and more spray activity more than four years ago (57\% versus 51\%). Government health services sprayed nearly all the houses, with less than $1 \%$ covered by a private company at personal cost. The odds of a household member reporting malaria illness in the past year for houses sprayed with insecticide within that year was significantly higher than houses that had been sprayed more than one year ago $(\mathrm{OR}=1.6, P=0.03)$. When asked if respondents would be willing to pay 30,000 rupiah ( US \$3) to have their house sprayed, only 45 (5\%) said yes; however, 989 respondents $(99 \%)$ would agree to have their house sprayed if the service was offered at no charge.

Government malaria control program. With regards to government malaria control activities, respondents prioritized indoor residual spraying (31\%), information dissemination and education $(27 \%)$, and provision of medication and health workers $(18 \%)$ as most useful or desired. One hundred seventy-four respondents (17\%) were unaware of any organized government activities to control malaria, and 176 (18\%) stated that the government did not do anything to control malaria. Five hundred nineteen respondents (52\%) answered that government control of malaria is good or very good.

Sources of treatment. Figure 2 shows the number of days after malaria symptoms were noticed until advice/treatment was sought. Table 4 shows the reported primary sources of malaria treatment. Of the 409 households reporting a case of malaria in the past year, the initial diagnosis of malaria was provided by the following: health center $(30 \%)$, private health practitioner $(20 \%)$, family member or self $(18 \%)$, midwife $(13 \%)$, and local health post (12\%). Three hundred fifty-eight $(88 \%)$ of 409 households sought advice or treatment outside the home for the last reported malaria illness. The main sources consulted were health centers $(28 \%)$, private health care providers $(22 \%)$, and local drug vendors $(19 \%)$. Midwives were more likely to be cited by forest/hill residents. More than $10 \%$ of paddy/urban residents reported consulting a malaria cadre vice less than $1 \%$ of forest/hill residents.

The median time required to reach the place of consultation was 15 minutes (range $=0-240$ minutes). The modes of transportation to reach the first source of treatment were by foot $(51 \%)$, motorcycle $(23 \%)$, local village transport vans $(16 \%)$, and bicycles $(7 \%)$. Two hundred eleven respondents $(52 \%)$ treated the last malaria illness in the family with medicine without going to a health facility.

Of 359 households who sought treatment of malaria outside the home, 107 (30\%) sought a second opinion, primarily with private practitioners or health centers. The modes of transportation used to reach the second source of treatment were by foot $(25 \%)$, motorcycle $(38 \%)$, local bicycle-pulled transport $(29 \%)$, and bicycles $(6 \%)$.

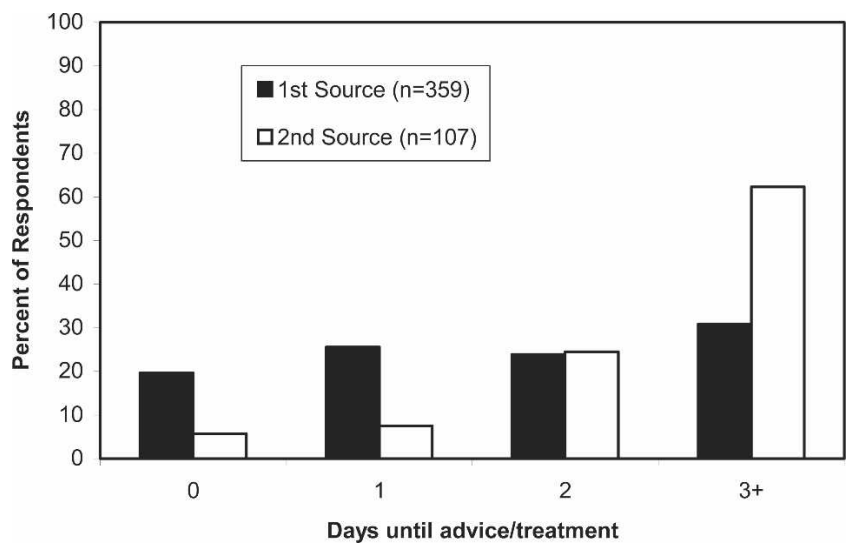

FIGURE 2. Number of days after malaria symptoms were noticed until advice/treatment was sought in Purworejo District, Indonesia, May-July 2001. 
TABLE 4

Sources of primary treatment for malaria $(n=409)$ in Purworejo District, Indonesia, May-July 2001

\begin{tabular}{lcccc}
\hline \multicolumn{1}{c}{ Source of treatment } & \% Hills/forest & \% Paddy/urban & \% Total & $P$ \\
\hline Health center & 28.9 & 30.7 & 29.8 & 0.703 \\
Private practitioner & 20.8 & 18.4 & 19.6 & 0.538 \\
Family member & 21.8 & 14.6 & 18.1 & 0.475 \\
Midwife & 16.2 & 9.4 & 12.7 & $0.039^{*}$ \\
Health post & 10.2 & 14.2 & 12.2 & 0.217 \\
Malaria cadre & 0.5 & 10.8 & 5.9 & $<0.001^{*}$ \\
Other & 1.0 & 1.9 & 1.5 & 0.464 \\
\hline * Significant difference. & & & &
\end{tabular}

Medication. Respondents were asked to describe the source of malaria medication used to treat the last case of malaria in the household. Patients who sought treatment without going to a health facility obtained medication primarily from local drug vendors (64\%) and community health workers $(25 \%)$. Of the 409 households affected by malaria in the last year, $74 \%$ received medicine from a health facility. Overall, a median of five pills (range $=0-54$ ) was given to the malaria patient for a three-day treatment regimen. Of the 404 malaria patients who received medication from any source, $363(90 \%)$ reported that the prescribed course of medication was completed. Table 5 shows the distribution of medications used for treatment.

Primaquine. Primaquine treatment was reported by 231 households $(73 \%)$ self-reporting malaria in the past year. Primaquine was obtained from government health facilities as a normal course of treatment. Patients took primaquine for a median of three days (range $=1-13$ days). Of the 231 patients who reported taking primaquine, $215(93 \%)$ reported taking all prescribed tablets. There was no difference between the recurrence of malaria in patients treated with primaquine compared with patients who did not receive primaquine (OR $=0.9, P=0.769)$.

Relapse. Malaria symptoms were reported as cured within three days of start of medication in 353 (87\%) of cases interviewed. However, 74 patients $(18 \%)$ reported becoming ill with malaria within one month of taking malaria medication.

Relapse or re-infection was reported by 48 households $(23 \%)$ who treated the most recent malaria patient with medicine obtained outside a health facility. The odds of recurrent illness in patients who self-treated compared with patients who sought treatment from a health facility was $1.95(P=$ 0.012).

Cost of treatment. The median cost of treatment reported by those who first self-treated was 6,000 rupiah ( US \$0.6). The median cost of treatment reported by those who sought

TABLE 5

Reported medication used for treatment by patients self-treating and by patients who visited a health facility in Purworejo District, Indonesia, May-July 2001 (multiple responses possible)

\begin{tabular}{|c|c|c|c|}
\hline Medication & $\begin{array}{c}\% \text { of self-treated } \\
\text { patients }(\mathrm{n}=211)\end{array}$ & $\begin{array}{l}\% \text { of patients } \\
\text { treated at a health } \\
\text { facility }(\mathrm{n}=303)\end{array}$ & $P$ \\
\hline Do not know & 27.0 & 59.5 & $<0.001 *$ \\
\hline Chloroquine & 36.0 & 38.5 & 0.602 \\
\hline Quinine & 19.0 & 0.7 & $<0.001^{*}$ \\
\hline Fansidar $\dagger$ & 5.7 & 0.7 & $0.001 *$ \\
\hline Other & 17.5 & 1.6 & $<0.001 *$ \\
\hline
\end{tabular}

treatment outside the home was 7,250 rupiah ( US\$0.7). However, this difference was not statistically significant $(P=$ $0.2)$.

\section{DISCUSSION}

Most people in the malaria-endemic hill areas of Purworejo District expressed an understanding of malaria transmission, symptoms, and consequences of inadequate treatment. Fiftytwo percent reported self-treatment and were found at higher risk of reporting recurrent malaria than those seeking initial treatment at health centers. Surveyed knowledge of malaria prevention measures showed a generally poor understanding. Although some households owned bed nets (36\%), few (36\% of households with bed nets) linked net use with prevention of malaria. Conversely, $7 \%$ of households reporting bed net use as the most important means of malaria prevention did not own a net. Perhaps most problematic was the widely held (55\%) perception that good housekeeping prevented malaria. The abundance and bionomics of forest and creek breeding mosquito vectors in this region (predominantly Anopheles maculatus and An. balabacensis) would not likely be impacted by simply maintaining tidiness of homes and immediate surrounding landscapes. A previous case-control survey study of environmental and behavioral risk factors for malaria in the region found significant correlation only with nighttime exposure to springs and creeks. ${ }^{8}$ These primary vectors prefer to rest out-of-doors, and such behavioral patterns complicate vector control strategies and effectiveness.

Several risk factors for malaria emerged from the survey. Homes constructed of wood or bamboo lacking sufficient window coverings (barriers to mosquito entry) accounted for a significantly higher risk of reporting malaria during the previous year. The odds of having a household member selfreporting malaria in the past year in a house with glass over windows is 1.8 times less than for households with partial or no glass over windows $(P<0.0001)$. These domestic risk factors may be confounded by socioeconomic status. The significantly higher risk of reporting malaria in the past year among households receiving indoor residual insecticide within that 12 months $(\mathrm{OR}=1.6, P=0.006)$ was attributed to an operational selection bias by health authorities directing their limited resources to areas at highest risk. Spray operations were often sporadic in response to ongoing malaria outbreaks and not universal in area coverage. Owning a bed net was not associated with risk of reporting malaria in the past year $(\mathrm{OR}=1.0, P=0.892)$.

As reported elsewhere, ${ }^{9-12}$ we found residents of Purworejo preferring the apparent convenience of self- treatment as the first course of action, and seeking professional assistance only after failure to resolve the illness. A delay of three or more days between self-treatment and seeking additional help occurred among $60 \%$ of such events. In this study, only six households consulted hospitals as a treatment route and in all but one case, hospitals were visited as the final treatment option. The reported expenditure by patients taken to a hospital for a second opinion $(n=5)$ was 350,000 rupiah ( $\sim$ US \$35) per patient. Prompt and adequate treatment may have averted malaria complications, eliminated the need for further treatment, and reduced overall expenditures. Increased community awareness of the economic consequences of delayed or insufficient treatment may improve treatmentseeking behavior, but residents are not likely to abandon the 
current practice in the absence of substantial improvement of economic conditions in the area.

Antimalarial drugs were widely available at local shops, pharmacies, and markets throughout Purworejo at a relatively low cost. A visit to the local pharmacy found chloroquine tablets sold in packets of four tablets for US $\$ 0.09$, quinine in packets of 12 tablets for US $\$ 0.42$ and sulfadoxinepyrimethamine (Fansidar ${ }^{\circledR}$; F. Hoffmann LaRoche, Basel, Switzerland) for US $\$ 1.50$ for three tablets. Paracetamol (acetaminophen) costs only US $\$ 0.02$ per tablet and is often used to treat fever and headaches. Although reported compliance was high (91\%), the described regimens were often substandard relative to recommended national treatment guidelines, mostly attributed to ignorance by patients and providers. An intervention campaign in rural Kenya that focused on providing shopkeepers with three days of practical training on the management of fevers found the percent of drug sales where an adequate amount of antimalarial drug was purchased increased from $32 \%$ to $83 \%$ and the percent of childhood fevers treated with an adequate dose of chloroquine increased from $4 \%$ to $65 \% .{ }^{13}$ Furthermore, shop keepers were eager to participate in these workshops because it increased their confidence, knowledge, profits, and overall status in the community. ${ }^{13}$

Numerous surveys attempting to assess knowledge, attitudes, and practices related to malaria and treatment-seeking behavior have been conducted in communities in The Philippines, Kenya, Solomon Islands, Togo, Uganda, Malawi, and other countries. ${ }^{9-12,14-24}$ The results from these studies emphasize the need for community-specific information on perception and knowledge of illness, the prevalence and severity of disease, and local health-seeking behavior to enable policy makers and program managers to design more effective and appropriate malaria control programs.

In summary, we surveyed 1,000 randomly selected households on their knowledge, attitudes, and practices in the most malaria-endemic areas of Purworejo District on the southern coast of central Java, Indonesia during a prolonged epidemic of malaria. Home construction (plank wood or bamboo without window coverings) was a significant risk factor for households reporting malaria in the past year. Self-treatment of malaria was widespread (54\%) and a significant risk factor for recurrent disease. Bed net ownership did not appear to impact risk of reporting malaria in the past year. The most prevalent household practice aimed at preventing malaria was good housekeeping, thus revealing common misconceptions about sound personal protection and vector intervention measures.

Received January 11, 2006. Accepted for publication March 28, 2006.

Acknowledgments: We thank Dr. Shannon Putman for his thoughtful review.

Financial support: This work was supported by the U.S. Department of Defense Global Emerging Infections Surveillance Program. Parsa Sanjana completed this work as part of a master's thesis at Emory University.

Disclaimer: The views and opinions are those of the authors and do not purport to represent those of the U.S. Navy or Department of Defense.

Authors' addresses: Parsa Sanjana, Family Health International, 3100 Connecticut Ave NW, \#220 Washington, DC 20008. Mazie J. Barcus, Hydas World Health, 2061 Winged Foot Court, Reston, VA 20191.
Michael J. Bangs, U.S. Navy Disease Vector Ecology and Control Center Bangor, 2850 Thresher Avenue, Silverdale, WA 98315-0304. Sahat Ompusunggu, Harijani Marwoto, and Sekar Tuti, LITBANGKES, Departemen Kesehatan Jl, Percetakan Negara No. 29, Jakarta 10560 Indonesia. Iqbal Elyazar, U.S. Embassy, Jakarta, Unit 8132, Naval Medical Unit 2, FPO AP 96520-8132. J. Kevin Baird, Director, ALERTAsia Foundation, Eijkman Institute of Molecular Biology, Jalan Diponegoro No. 69, Menteng, Jakarta 10430, Indonesia, E-mail: jkevinbaird@yahoo.com. Mohammed Sururi, Dinas Kesehatan Kabupaten Jl, May, Jend, Sutoyo 17, Purworejo, Indonesia. Soesanto Tjokrosonto, Gadja Mada University, Yogyakarta, Indonesia.

Reprint requests: Commanding Officer, U.S. Naval Medical Research Unit No. 2, American Embassy Jakarta, FPO AP 96520-8132 USA, Attn: Publications Office.

\section{REFERENCES}

1. World Health Organization, 1998. Fact Sheet 94: Malaria. Geneva: World Health Organization.

2. Baird JK, 2000. Resurgent malaria in the millennium: control strategies in crisis. Drugs 59: 719-743.

3. Kachur SP, Boland PB, 1998. Diseases transmitted primarily by arthropod vectors: malaria. Wallace RJ, ed. Public Health and Preventive Medicine: Stamford, CT: Appleton and Lange, 313326.

4. Kondrashin AV, Rashid KM, 1987. Epidemiological Considerations for Malaria Control in South-East Asia Region: Indonesia. Geneva: World Health Organization. WHO Regional Publication: Southeast Asia Series, 411.

5. Baird JK, Sismadi P, Masbar S, Ramzan A, Purnomo BW, Sekartuti, Tjitra E, Rumoko BW, Arbani PR, 1996. A focus on endemic malaria in central Java, Indonesia. Am J Trop Med Hyg 54: 98-104.

6. Barcus MJ, Laihad F, Sururi M, Sismadi P, Marwoto H, Bangs MJ, Baird JK, 2002. Epidemic malaria in the Menoreh Hills of central Java. Am J Trop Med Hyg 66: 287-292.

7. Dinas Kesehatan Kabupaten, 2000. Situasi Malaria dan Upaya Penanggulangannya di Kabupaten Purworejo. District Department of Health Annual Malaria Report].

8. Herdiana E, 2001. Environmental and behavioral risk factors for malaria prevalence rate at Girimulyo Village, Menoreh Hill, Java, Indonesia. Indian J Clin Epidemiol Biostat 8: 6-9.

9. Nyamongo IK, 2002. Health care switching behaviour of malaria patients in a Kenyan rural community. Soc Sci Med 54: 377-386.

10. Dulhunty JM, Yohannes K, Kourleoutov C, Manuopangai VT, Polyn MK, Parks WJ, Bryan JH, 2000. Malaria control in central Malaita, Solomon Islands: local perceptions of the disease and practices for its treatment and prevention. Acta Trop 75: 185-196.

11. Espino F, Manderson L, 2000. Treatment seeking for malaria in Morong, Bataan, the Philippines. Soc Sci Med 50: 1309-1316.

12. Utarini A, Winkvist A, Ulfa FM, 2003. Rapid assessment procedures of malaria in low endemic countries: community perceptions in Jepara district, Indonesia. Soc Sci Med 56: 701-712.

13. Marsh VM, Mutemi WM, Muturi J, Haaland A, Watkins WM, Otieno G, Marsh K, 1999. Changing home treatment of childhood fevers by training shop keepers in rural Kenya. Trop Med Int Health 4: 383-389.

14. Deming MS, Gayibor A, Murphy K, Jones TS, Karsa T, 1989. Home treatment of febrile children with antimalarial drugs in Togo. Bull World Health Organ 67: 695-700.

15. Espino F, Manderson L, Acuin C, Domingo F, Ventura E, 1997. Perceptions of malaria in a low endemic area in the Philippines: transmission and prevention of disease. Acta Trop 63: 221-239.

16. Kengeya-Kayondo JF, Seeley JA, Kajura-Bajenja E, Kabunga EME, Sembajja F, Mulder DW, 1994. Recognition, treatment seeking behaviour and perception of cause of malaria among rural women in Uganda. Acta Trop 58: 267-273.

17. McCombie SC, 1996. Treatment seeking for malaria: a review of recent research. Soc Sci Med 43: 933-945.

18. Miguel CA, Manderson L, Lansang MA, 1998. Patterns of treatment for malaria in Tayabas, the Philippines: implications for control. Trop Med Int Health 3: 413-421. 
19. Miguel CA, Tallo VL, Manderson L, Lansang MA, 1999. Local knowledge and treatment of malaria in Agusan del Sur, The Philippines. Soc Sci Med 48: 607-618.

20. Ruebush TK, Kern MK, Campbell CC, Oloo AJ, 1995. Selftreatment of malaria in a rural area of western Kenya. Bull World Health Organ 73: 229-236.

21. Schultz LJ, Ettling M, Chitsulo L, Steketee RW, Nyasulu Y, Macheso A, Nwanyanwu OC, 1994. A nation-wide malaria knowledge, attitudes and practices survey in Malawi: objectives and methodology. Trop Med Parasitol 45: 5456.
22. Tanner M, Vlassoff C, 1998. Treatment-seeking behavior for malaria: a typology based on endemicity and gender. Soc Sci Med 46: 523-532.

23. Njama D, Dorsey G, Guwatudde D, Kigonya K, Greenhouse B, Musisi S, Mr K, 2003. Urban malaria: primary caregivers knowledge, attitudes, practices and predictors of malaria incidence in a cohort of Ugandan children. Trop Med Int Health 8 . 685-692.

24. Adera TD, 2003. Beliefs and traditional treatment of malaria in Kishe settlement area, southwest Ethiopia. Ethiop Med J. 41: $25-34$. 